\title{
MAGNESIUM METABOLISM FOLLOWING SPINAL CORD INJURY
}

\author{
By A. Broughton and R. G. BurR
}

R.A.F. Institute of Pathology and Tropical Medicine, Halton, Aylesbury, and National Spinal Injuries Centre, Stoke Mandeville Hospital, Aylesbury, Bucks.

\section{INTRODUCTION}

MAGNESIUM depletion in man can occur associated with primary aldosteronism, prolonged or severe fluid loss, diuretic therapy, alcoholism, hypercalcaemia, malabsorption, or following the removal of a parathyroid adenoma (Fraser \& McIntyre, I970). The symptoms of pure magnesium deficiency may include depression, irritability, aggressiveness, disorientation, hallucinations, vertigo, ataxia, tremor, epileptiform convulsions and muscular weakness (Hanna et al., I960; Smith, 1963).

Broughton et al. (I968) observed hypomagnesaemia in eight out of 20 patients with burns. Five of the eight exhibited symptoms of magnesium deficiency and it was thought that this state may have been associated with secondary hyperaldosteronism. Paraplegic patients were observed to have an increased urinary magnesium I-2 weeks after onset (R. G. Burr, unpublished observations), and in view of the occasional appearance among acute paraplegics of psychiatric symptoms resembling those of magnesium deficiency (J. J. Walsh, Personal communication) it was decided to examine the possibility of magnesium deficiency in paraplegia.

\section{PATIENTS AND METHODS}

Two groups of patients were studied. Group I consisted of I6 traumatic paraplegics ( 13 male and 3 female) admitted within 5 days of spinal cord injury (Table I). The total urinary output of the male patients was collected daily for a minimum of 3 weeks and of the female patients until they began to pass urine spontaneously. The urines were analysed for calcium, magnesium, sodium, potassium, inorganic phosphate, creatinine and in some patients nitrogen. Venous blood was taken at intervals of 3-4 days for the estimation of calcium, magnesium, sodium and potassium.

Group 2 consisted of ten other patients with traumatic paraplegias of varying duration, showing symptoms suggestive of magnesium deficiency (Table II). Blood was taken at this time for the estimation of calcium and magnesium.

Calcium and magnesium were measured by atomic absorption spectrophotometry, sodium and potassium by flame photometry, inorganic phosphate and creatinine by the autoanalyser (Technicon Ltd.). The urinary nitrogen was estimated as follows: I ml. of a I in IOoO dilution of urine was mixed with I ml. of a solution containing $2 \mathrm{~g}$. $\mathrm{SeO}_{2}$ and $70 \mathrm{ml}$. concentrated $\mathrm{H}_{2} \mathrm{SO}_{4}$. After digestion, $2 \mathrm{ml}$. of a solution containing $\mathrm{I} 5 \mathrm{~g}$. phenol and $0.075 \mathrm{~g}$. sodium nitroprusside per litre were added, followed by $4 \mathrm{ml}$. of a solution containing $35.8 \mathrm{~g}$. $\mathrm{Na}_{2} \mathrm{HPO}_{4}$ $\mathrm{I}_{2} \mathrm{H}_{2} \mathrm{O}, \mathrm{I} 7.5 \mathrm{~g}$. $\mathrm{NaOH}$ and $0.3 \mathrm{I} 7 \mathrm{~g}$. NaOCl per litre. After 30 minutes extinctions were read at $625 \mathrm{~nm}$. 


\section{TABLE I}

Details of Patients in Group I

\begin{tabular}{|c|c|c|c|c|c|}
\hline \multirow{2}{*}{ Patient } & \multicolumn{2}{|c|}{ Spinal cord lesion } & \multirow[b]{2}{*}{ Age } & \multirow[b]{2}{*}{ Sex } & \multirow[b]{2}{*}{ Associated injuries } \\
\hline & Level* & $\begin{array}{l}\text { Complete/ } \\
\text { incomplete }\end{array}$ & & & \\
\hline W. M. & TII & $c$ & 40 & M & none \\
\hline M. M. & $\mathrm{C}_{7}$ & $i$ & I8 & $M$ & fractures, lacerations \\
\hline R. S. & $\mathrm{C}_{5}$ & $i$ & 25 & M & lacerations \\
\hline R. D. & T6 & $i$ & 40 & M & lacerations \\
\hline T. M. & $\mathrm{C}_{4}$ & $i$ & I8 & M & none \\
\hline W. V. & L3 & $c$ & 27 & M & none \\
\hline D. G. & C6 & $c$ & 17 & $\mathbf{M}$ & none \\
\hline C. D. & T8 & $c$ & 19 & M & none \\
\hline F. D. & $\mathrm{T}_{4}$ & $c$ & 26 & M & none \\
\hline K. W. & $\mathrm{T} 9$ & $c$ & 24 & M & none \\
\hline A. J. & $\mathrm{C}_{4}$ & $i$ & 66 & $M$ & none \\
\hline P. L. & T8 & $c$ & 24 & M & $\begin{array}{l}\text { concussion, abrasions, } \\
\text { haemothorax }\end{array}$ \\
\hline E. R. & $\mathrm{C}_{5}$ & $i$ & 46 & $\mathrm{M}$ & lacerations \\
\hline D. B. & T6 & $c$ & 26 & $\mathrm{~F}$ & abrasions \\
\hline W. C. & LI & $c$ & I6 & $\mathrm{F}$ & abrasions, lacerations \\
\hline D. T. & $\mathrm{L}_{3}$ & $c$ & 19 & $\mathrm{~F}$ & none \\
\hline
\end{tabular}

* $\mathrm{C}=$ cervical cord lesion; $\mathrm{T}=$ thoracic cord lesion; $\mathrm{L}=$ lumbar cord lesion.?

\section{RESULTS}

The 16 patients in Group I showed an increased excretion of magnesium, potassium and inorganic phosphate which reached a maximum between the 5 th and I 5 th day then declined to a constant level within the normal range. Four of the I6 patients showed an elevated serum magnesium for a period of, I, 6, 8 and Io days respectively, which corresponded with the period of increased urinary excretion. The serum and urinary magnesium on one of these patients are shown in Figure I.

A serum magnesium level below the limit of normal ( $\mathrm{r} \cdot 4 \mathrm{mEq} . / \mathrm{l}$.) was observed on one occasion in two of the I6 patients (fig. 2). One of these (K. W.) had a transient dip ( $1 \cdot 25 \mathrm{mEq} . / 1$.) corresponding to the peak in urinary excretion, and the other (W. C.) showed a shallow depression, the lowest point of which ( $1 \cdot 35 \mathrm{mEq} . / \mathrm{l}$.) coincided with a low serum sodium. No urine results were available from this patient because she was by this time incontinent.

Another patient (D. B. in Table I) was pregnant and nearing term at the time of injury. Delivery (stillbirth) on the 6th day was accompanied by an abrupt fall in serum magnesium from $2.0 \mathrm{mEq} . / 1$. to $\mathrm{I} \cdot 4 \mathrm{mEq} . / 1$ and a rise in urinary magnesium (fig. 3). The remaining nine patients had a normal serum magnesium throughout the whole period of the investigation.

There was a statistically significant correlation $(P<0.05)$ between magnesium 
TABLE II

Details of Patients in Group 2

\begin{tabular}{|c|c|c|c|c|c|c|c|c|}
\hline \multirow{2}{*}{ Patient } & \multirow[b]{2}{*}{ Age } & \multicolumn{2}{|c|}{ Spinal cord lesion } & \multirow{2}{*}{ Sex } & \multirow[b]{2}{*}{$\begin{array}{l}\text { Duration of } \\
\text { paraplegia }\end{array}$} & \multirow{2}{*}{ Symptoms } & \multirow{2}{*}{$\underset{\text { magnesium }}{\text { Serum }}$} & \multirow{2}{*}{$\begin{array}{c}\text { Serum } \\
\text { calcium } \\
\text { (mEq./1.) }\end{array}$} \\
\hline & & Level* & $\begin{array}{l}\text { Complete/ } \\
\text { incomplete }\end{array}$ & & & & & \\
\hline I & $5 \mathrm{I}$ & $\mathrm{C}_{5}$ & $c$ & M & $40 \mathrm{~d}$ & confusion, disorientation & $2 \cdot 10$ & $4 \cdot 40$ \\
\hline 2 & 25 & $\mathrm{C}_{5}$ & $i$ & $M$ & $8 \mathrm{~d}$ & confusion & $2 \cdot 15$ & $4 \cdot 55$ \\
\hline 3 & 20 & $\mathrm{~T}_{4}$ & $i$ & $\mathrm{~F}$ & $4 \mathrm{~m}$ & confusion & $I \cdot 70$ & $5 \cdot 00$ \\
\hline 4 & 7I & $\mathrm{C} 4$ & $i$ & $\mathrm{~F}$ & $5 \mathrm{~d}$ & confusion & $I \cdot 55$ & $4 \cdot 15$ \\
\hline 5 & 66 & $\mathrm{C}_{5}$ & $c$ & M & I $7 \mathrm{~d}$ & confusion, drowsiness & $\mathrm{I} \cdot 75$ & $4 \cdot 50$ \\
\hline 6 & 54 & $\mathrm{C}_{5}$ & $c$ & M & I3 d & $\begin{array}{l}\text { confusion, drowsiness } \\
\text { (dehydration) }\end{array}$ & $I \cdot 85$ & 3.85 \\
\hline 7 & 60 & $\mathrm{C}_{5}$ & $i$ & M & $5 \mathrm{~m}$ & $\begin{array}{l}\text { dementia, confusion } \\
\text { (? cerebral degeneration) }\end{array}$ & $I \cdot 65$ & $4 \cdot 65$ \\
\hline 8 & 27 & $\mathrm{~L}_{3}$ & $i$ & M & $2 \mathrm{~m}$ & confusion & $I \cdot 50$ & $5 \cdot 45$ \\
\hline 9 & 23 & $\mathrm{C}_{5}$ & $i$ & $M$ & $33 \mathrm{~d}$ & depression, irritability & $I \cdot 75$ & $4 \cdot 25$ \\
\hline IO & 53 & $\mathrm{C}_{5}$ & $i$ & $\mathrm{~F}$ & $3 y$ & depression & $I \cdot 55$ & $4 \cdot 95$ \\
\hline
\end{tabular}

* $\mathrm{C}=$ cervical cord lesion; $\mathrm{T}=$ thoracic cord lesion; $\mathrm{L}=$ lumbar cord lesion. 

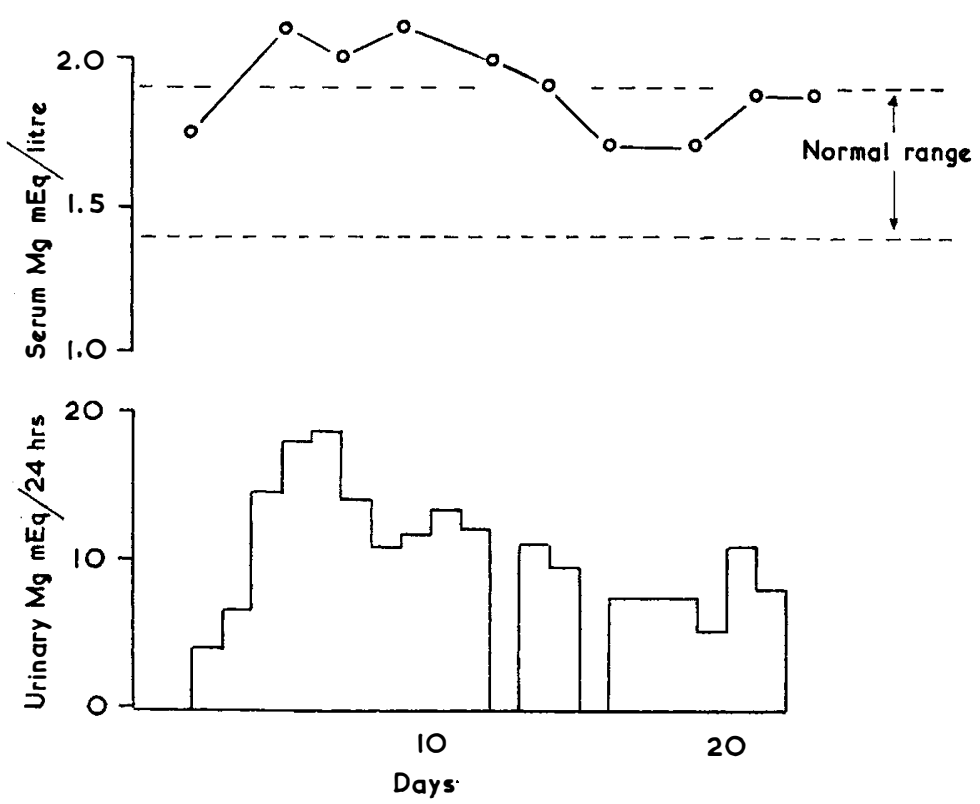

FIG. I

Serum and urinary magnesium levels in one of the patients with a transiently elevated serum magnesium.

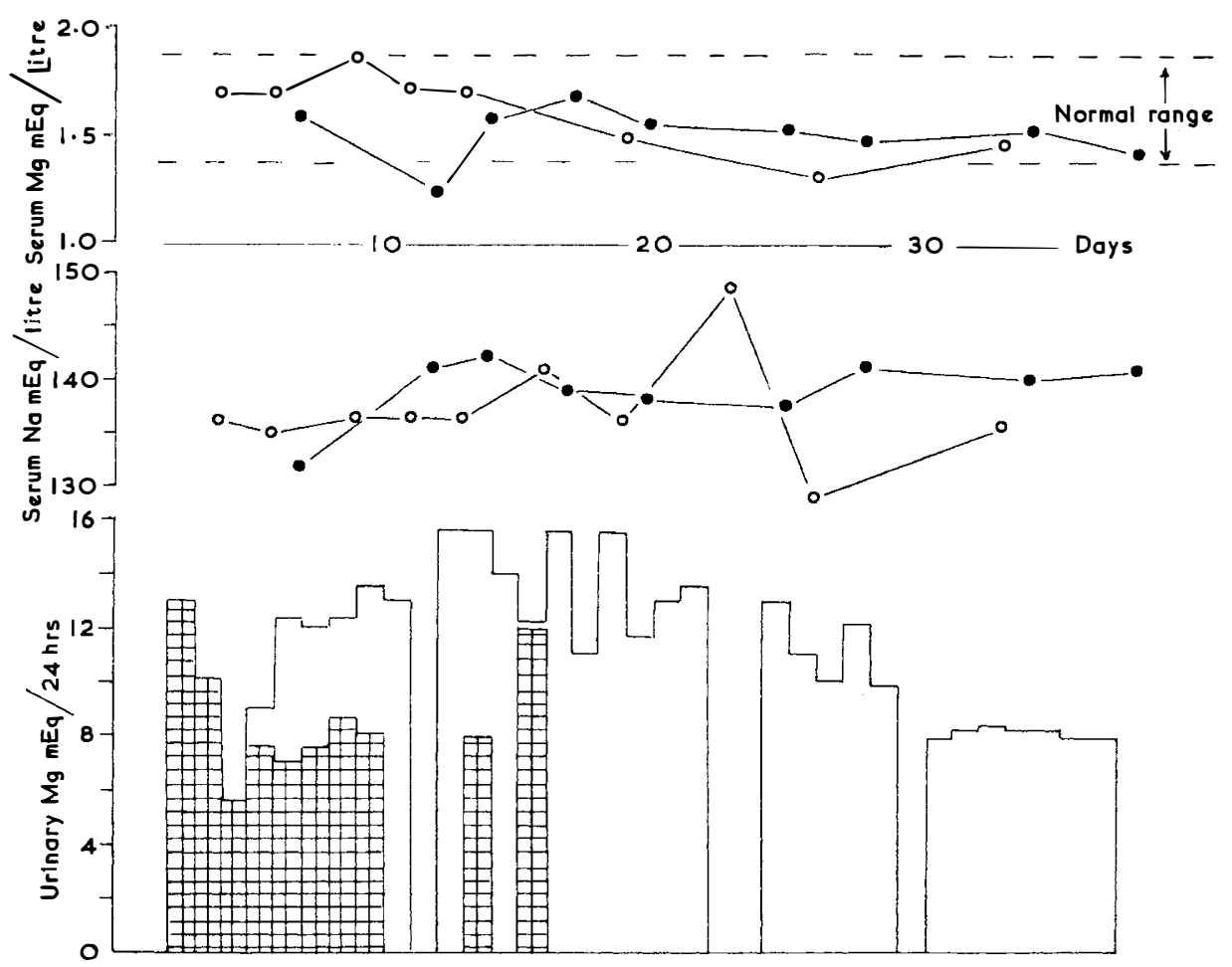

FIG. 2

Serum magnesium and sodium levels together with the urinary output of magnesium in the two patients with a low serum magnesium. Patient W. C. is shown as the open circles and the hatched histogram, and K. W. as closed circles and unhatched histogram. 


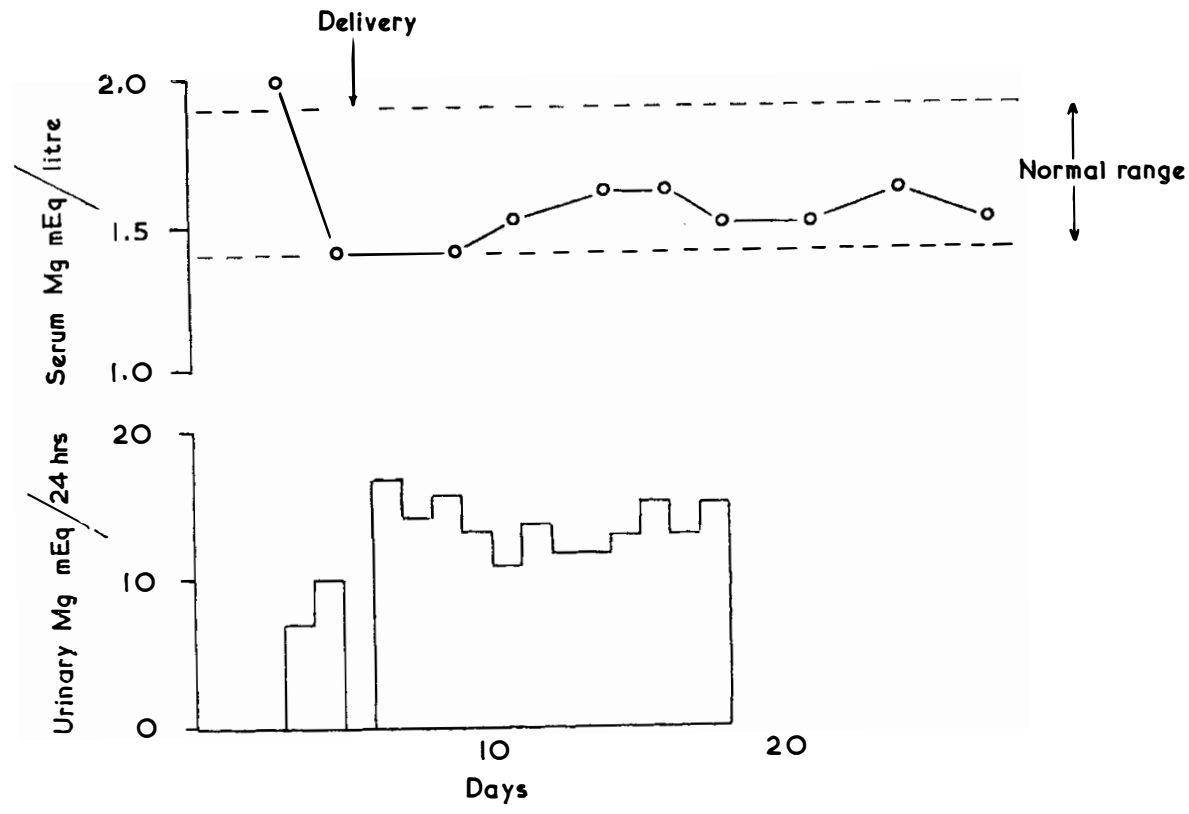

FIg. 3

Serum and urine magnesium levels in patient D. B.

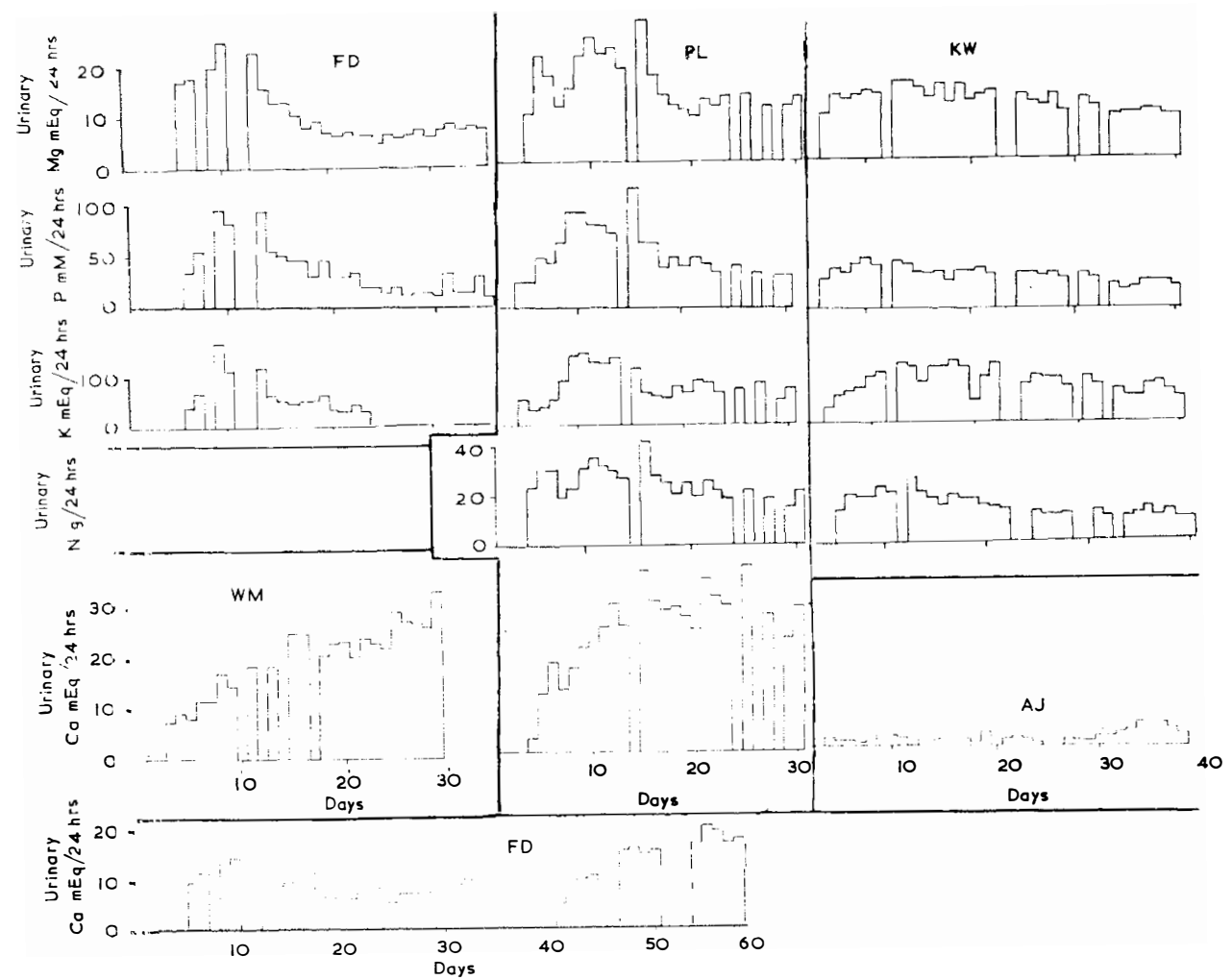

FIG. 4

Urinary excretion of magnesium, phosphorus, potassium, nitrogen and calcium in a selection of the patients studied. 
and phosphate excretion in eight of the I6 patients; two of the 16 showed a significant correlation between magnesium and potassium excretion $(P<0.05)$ and seven between potassium and phosphate excretion $(P<0.05)$. The patterns of excretion found in three patients taken as representative are shown in Figure 4.

There was no correlation between the urinary magnesium and the urinary sodium/potassium ratio in any patient $(P>0.05)$.

The urinary calcium showed a more or less steady increase for the first 10-30 days of paraplegia (fig. 4). One patient (F. D.) on whom the study was continued for 60 days showed a delayed increase which did not commence until the $45^{\text {th }}$ day. Another patient (A. J.), aged 66, had a very low urinary calcium until the 30 th day, when there was a small increase (fig. 4).

There was no consistent pattern of sodium excretion.

Eight of the Io patients in Group 2 had serum magnesium levels within the normal range, the other two had slightly elevated levels (Table II).

\section{DISCUSSION}

A constant feature of the present series was the increased urinary magnesium lasting from 5 to Io days during the first 30 days following injury to the spinal cord. Other workers have reported that trauma is followed by increased blood and urinary magnesium (Beecher et al., I 947; Gillette et al., I958; Walker et al., I968) suggesting that the excretion of magnesium is secondary to its release from traumatised or atrophied cells. The parallel behaviour of urinary nitrogen, potassium and phosphate supports this conclusion.

The hypomagnesaemia found in two patients was transient and insufficient to produce symptoms. This contrasts with the prolonged fall in serum magnesium, in some cases to below $\mathrm{I} \cdot 0 \mathrm{mEq} . / 1$., observed in patients with burns (Broughton et al., I968). The abrupt fall of serum magnesium seen in patient D. B. (fig. 3) was unlikely to have been due to urinary loss because it coincided with, rather than followed, the increased urinary magnesium, and was probably associated with redistribution between the magnesium compartments. Hypomagnesaemia has previously been reported in parturition (Wallach et al., 1962) but no explanation was offered.

An increased excretion of aldosterone accompanies the sodium retention and potassium loss which follow surgery, and Llaurado (I957) suggested the use of the urinary potassium/sodium ratio as an index of aldosterone release. However, there is evidence that these phenomena are unrelated (Gowenlock \& Longson, 1970). Information relating to the effect of aldosterone on the renal handling of magnesium is conflicting. Horton and Biglieri (1962), studying patients with primary aldosteronism and also adrenalectomised patients, found that aldosterone increased the output of magnesium in the urine, but Lemann et al. (1970) found that neither aldosterone nor cortisol influenced the urinary excretion of magnesium in healthy man. Therefore it is not surprising that the present results reveal no correlation between the urinary magnesium and the sodium/potassium ratio.

Sixty-three per cent. of the total body magnesium is found in bone (Aikawa: 1964) and the increase in urinary calcium observed in paraplegics is known to be derived from bone (Chantraine, I97I). However, the increase in urinary magnesium following paraplegia is too large to be derived only from bone because the molar ratio of magnesium to calcium in bone is very small ( $\mathrm{I}: 50$ ) (Fraser \& McIntyre, 
I970). The increases of urinary magnesium, phosphate, potassium and nitrogen (fig. 4) were in the proportions expected from skeletal muscle (Diem, I962), but metabolic balance studies will be required to confirm this relationship.

Thus the increased urinary magnesium which follows the onset of paraplegia is probably related mainly to the increased load presented for excretion, which is derived from the catabolic response to trauma and the muscle wasting that results from paralysis.

The symptoms observed in the patients of Group 2 are unexplained but were not due to magnesium deficiency.

\section{SUMMARY}

Serial measurements of serum and urinary magnesium in I6 acute traumatic paraplegic patients revealed a period of increased urinary excretion of magnesium in all, associated in four of them with an elevated serum magnesium, and in two with transient hypomagnesaemia.

In ten other patients showing symptoms suggestive of magnesium deficiency the serum magnesium was within normal limits in eight, and elevated in two.

There is no evidence that magnesium deficiency is responsible for symptoms in paraplegia.

\section{RÉSUMÉ}

Le dosage du taux de magnésium sanguin et urinaire a été effectué chez I 6 paraplégiques post-traumatiques au cours de la période aigüe. Une augmentation du taux du magnésium dans l'urine a été notée chez tous, associée dans 4 cas avec une augmentation du magnésium sérique et dans 2 cas avec une diminution du taux sérique, transitoire.

Chez Io autres malades présentant des symptômes pouvant se reporter a une déficience en magnésium, le taux sérique de celui-ci a été normal dans 8 cas et augmenté dans les 2 autres cas.

Il n'y a pas d'évidence qu'une déficience en magnésium puisse être symptomatique chez le paraplégique.

\section{ZUSAMMENFASSUNG}

Bei I 6 akuten traumatischen Paraplegikern wurden Serienbestimmungen des Serumund Urinmagnesium angestellt. In allen Fällen bestand eine Periode von verstärkter Magnesiumsekretion im Urin, in 4 bestand auch ein erhöhtes Serum-Magnesium und in 2 Fällen eine vorübergehende Hypomagnesaemia.

In Io weiteren Fällen, die Symptome von Magnesiummangel zeigten, war das SerumMagnesium in 8 Fällen normal und in 2 erhöht.

Es besteht kein Beweiss, dass Magnesiummangel für Symptome in Paraplegie verantwortlich ist.

Acknowledgments. We thank Air Commodore Mortimer and Dr. J. J. Walsh for their advice, Dr. F. E. Lipscomb for preparing the figures, and the medical and nursing staff of the National Spinal Injuries Centre for their co-operation. One of us (A. B.) thanks the Director General of the R.A.F. Medical Services for permission to have this work published. 


\section{REFERENCES}

AIkawa, J. K. (1964). In Dynamic Clinical Studies with Radioisotopes (edited by R. M. Kniseley, W. N. Tauxe \& E. B. Anderson), p. 565. U.S. Atomic Energy Commission.

Beecher, H. K., Simeone, F. A., Burnett, C. H., Shapiro, S. L., Sullivan, E. R. \& MALlORY, T. B. (1947). The internal state of the severely wounded man on entry to the most forward hospital. Surgery, 22, 672 .

Broughton, A., Anderson, I. R. M. \& Bowden, C. H. (1968). Magnesium-deficiency syndrome in burns. Lancet, 2 , I 156.

Chantraine, A. (I97I). Clinical investigation of bone metabolism in spinal ocrd lesions. Int. F. Paraplegia, 8, 253.

DiEm, K. (Ed.) (1962). Documenta Geigy Scientific Tables, 6th Ed., p. 516. Manchester: Geigy.

Fraser, R. \& McInTyre, I. (1970). In Biochemical Disorders in Human Disease (edited by R. H. S. Thompson \& I. D. P. Wootton), 6th Ed., p. 75I. London: Churchill.

Gillette, R. W., Oppenheimer, J. H., Mansberger, A. R., Johnson, C. E. \& KookootSEDES, G. J. (1958). A new preparation for the study of experimental shock from massive wounds. V. Changes in some serum electrolytes and nitrogenous fraction values. Surgery, 43, 740.

Gowenlock, A. H. \& Longson, D. (1970). In Biochemical Disorders in Human Disease (edited by R. H. S. Thompson \& I. D. P. Wootton), 6th Ed., p. 35I. London: Churchill.

Hanna, S., Harrison, M., McIntyre, I. \& Fraser, R. (1960). The syndrome of magnesium deficiency in man. Lancet, $2,172$.

HORTON, R. \& BIGLIERI, E. G. (I962). Effect of aldosterone on the metabolism of magnesium. F. clin. Endocr. Metab. 22, I 187.

Lemann, J., Piering, W. F. \& LenNon, E. J. (1970). Studies of the acute effects of aldosterone and cortisol on the interrelationships between renal sodium, calcium and magnesium excretion in normal man. Nephron, 7, I I7.

LLAURADO, J. G. (1957). Aldosterone excretion following hypophysectomy in man; relation to urinary $\mathrm{Na} / \mathrm{K}$ ratio. Metabolism, 6, 556 .

SMIth, W. O. (1963). Magnesium deficiency in the surgical patient. Amer. F. Cardiol. 12, 667 .

WALKeR, W. F., Fleming, L. W. \& STEWART, W. K. (1968). Urinary magnesium excretion in surgical patients. Br. F. Surg. 55, 466.

Wallach, S., Cahill, L. N., Rogan, F. H. \& Jones, H. L. (I962). Plasma and erythrocyte magnesium in health and disease. F. Lab. clin. Med. 59, 195. 